\title{
TEACHING
}

AND TEACHER

EDUCATION

\section{Developing fundamental principles for teacher education programs and practices}

\author{
Fred Korthagen $^{\mathrm{a}, *}$, John Loughran ${ }^{\mathrm{b}}$, Tom Russell ${ }^{\mathrm{c}}$ \\ ${ }^{a}$ Vrije Universiteit, Amsterdam \& Utrecht University, P.O. Box 80127, 3508 TC Utrecht, The Netherlands \\ ${ }^{\mathrm{b}}$ Monash University, Australia

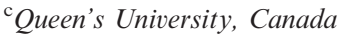

\begin{abstract}
Traditional approaches to teacher education are increasingly critiqued for their limited relationship to student teachers' needs and for their meager impact on practice. Many pleas are heard for a radical new and effective pedagogy of teacher education in which theory and practice are linked effectively. Although various attempts to restructure teacher education have been published, no coherent body of knowledge exists about central principles underlying teacher education programs that are responsive to the expectations, needs and practices of student teachers. By analyzing effective features of programs in Australia, Canada, and the Netherlands, this study contributes an initial framework of seven fundamental principles to guide the development of responsive teacher education programs that make a difference.
\end{abstract}

(C) 2006 Elsevier Ltd. All rights reserved.

Keywords: Pedagogy of teacher education; Theory-practice-relationship; Teacher educators

\section{Introduction}

The field of teacher education is recognized here as one whose problems have been generally well known since the turn of the century... [yet] the troublesome circumstances remain basically unchanged (Lanier \& Little, 1986, p. 527).

As Lanier and Little (1986) indicate, teacher education has long been characterized as a field of study that is of little importance to the academy. They highlighted the point that teacher educators themselves were often not even a part of research

\footnotetext{
${ }^{*}$ Corresponding author. Tel.: + 31302710692 ; fax: + 31302534262

E-mail address: f.a.j.korthagen@ivlos.uu.nl (F. Korthagen).
}

conducted into their work. This situation gradually changed through the 1990s as the:

voices of university researchers, of law makers, and of policy analysts, speaking about what teacher educators do or fail to do... [began to be challenged by] teacher educators discussing their own work [as] they describe their aspirations for the teachers they teach, their methods for realizing their aspirations, [and] the concepts and theories that ground these methods (Fenstermacher, 1997, p. viii).

In this new century, teacher education is beginning to be better recognized and valued as an object of academic research. There is a certain urgency for this research on teacher education to be carried out 
as, for several reasons, teacher education finds itself in a difficult position. Consider the following three points:

First, complaints from graduates of teacher education programs, school administrators, parents and politicians about the irrelevance of teacher preparation for the reality of everyday practice in schools have generated pressures to rethink both the structure and the practices of teacher education (Barone, Berliner, Blanchard, Casanova, \& McGowan, 1996; Sandlin, Young, \& Karge, 1992). In fact, as Bullough and Gitlin (2001) note, the teacher education program in which they "first worked together was disjointed, fragmented and confusing [for] methods courses were disconnected from curriculum courses, and both were disconnected from practice teaching" (p. 1). Further, as Ben-Peretz (1995) emphasized, traditional approaches to teacher education are generally characterized by a strong emphasis on theory that is "transferred" to teachers in the form of lectures on psychology, sociology, and general education. In traditional models of teacher education, teaching practice is usually seen as the opportunity to apply previously learned theories (Carlson, 1999; Clandinin, 1995) and lecturing appears to be viewed as an appropriate form of teaching about teaching; this theory-into-practice view of teacher education is increasingly being challenged for its many limitations and inadequacies.

Second, during the final decades of the 20th century, more and more research presented evidence that there were reasonable grounds for some of the complaints about teacher education. A strand of research studies documented the phenomenon of the reality shock faced by new teachers: not only did graduates of teacher education appear to experience severe problems during their first period in the profession (Veenman, 1984), but also a "washingout" effect of insights gained during teacher preparation was inferred, raising doubts about whether the insights from teacher education had actually been achieved (Cole \& Knowles, 1993; Zeichner \& Tabachnick, 1981). Teachers appeared to go through a distinct attitudinal shift, generally creating an adjustment to traditional ways of teaching (Müller-Fohrbrodt, Cloetta, \& Dann, 1978) and a dislike for reflection and theoretical depth (Cole, 1997). As Wideen, Mayer-Smith, and Moon (1998) concluded, the transfer from theory presented during teacher education to practice in schools is often meager and teacher education practices are often counterproductive to teacher learning.

Third, new conceptions of learning and teaching developed, such as constructivist views (Fosnot, 1996; Sigel \& Cocking, 1977), and new insights into the nature of knowledge started to surface, such as views of knowledge as situated (Brown, Collins, \& Duguid, 1989), strongly interwoven with experience and emotion (Cobb \& Bowers, 1999; Damasio, 1994). Importantly, these views contrast starkly with traditional practices in teacher education, the very same practices that were supposed to prepare teachers for new approaches to learning and teaching. In order to change educational practices, it is necessary to break the circle of traditionally trained teachers who teach in a traditional manner (Stofflett \& Stoddart, 1994). This represents a major challenge for teacher educators and researchers.

Late in the 20th century, a search for new ways of preparing teachers emerged. For example, one could observe a rise in the number of alternative certification programs (which often originated from the problem of teacher shortages) and a trend to create programs that were closely linked to professional development schools (Bullough \& Kauchak, 1997; Darling-Hammond, 1994). In such attempts to restructure teacher education, an emphasis on practice instead of theory came to the fore. It is noteworthy that in these situations, an inversion of the previous problem of reality shock often occurred: teacher education seemed to boil down to learning the tricks of the trade, without much deepening through theory. This meant that a basic problem was still not being addressed adequately, much less solved, namely, how to connect theory and practice in such a way that teachers would be able to handle the problems of everyday teaching through theory-guided action.

Ashton (1996) appealed for a search for a radical new and effective pedagogy of teacher education. During the last decade, this has been a major issue in teacher education in many countries. Reading accounts such as Tom (1997) may even lead teacher educators to believe that we are already working on the issue, as some teacher educators have published books focusing on new pedagogies of teacher education (for example, Bullough \& Gitlin, 2001; Korthagen, Kessels, Koster, Lagerwerf, \& Wubbels, 2001; LaBoskey, 1994; Loughran, 2006; Loughran \& Russell, 1997; Richardson, 1997; Segall, 2002) and issues concerning practices in teacher education are now regular topics at conferences on teaching 
and teacher education. However, for a number of reasons, these positive developments fall short of addressing some of the perennial and persistent dilemmas of teacher education.

As the report of the AERA Panel on Research and Teacher Education (Cochran-Smith \& Zeichner, 2005) has stressed, complex methodological issues are associated with attempts to establish an empirical basis for effective teacher education. Experimental designs are often impossible, as the number of variables involved is large and the variables are hard to control. Claims about what works often lack sufficient empirical support. More fundamentally, our knowledge concerning teacher education practices shows a gap between theory and practice. Every educator knows that even if we had substantial empirical knowledge from research, this knowledge could not simply be applied to concrete circumstances in specific institutions, such as situations with large student enrollments. Indeed, in thinking about fundamental change in the pedagogy of teacher education, there is a risk of making the same mistake as in preparing teachers: innovators may try to restructure teacher education either on the basis of research focusing on isolated issues (a research-based approach) or on the basis of practical circumstances within teacher education institutes (a practice-oriented approach). Again, the basic problem persists and begs the question: Can we integrate these two perspectives to arrive at a pedagogy of teacher education that is both empirically based and practically oriented? This paper addresses this problem by constructing the basis of a pedagogy of teacher education in the form of fundamental principles for teacher education programs and practices.

In order to do this, we first describe our approach to conducting this study and then provide a brief overview of features of three teacher education programs embedded in institutional contexts on three continents. By drawing from three ongoing cases of specific programs in which faculty are, or have been, trying to reconsider the nature of teacher education, we attempt to link theoretical insights about the professional development of teachers, on the one hand, with practice in teacher education, on the other. From our case studies, we have extracted seven fundamental principles for guiding program development and change, and we connect these principles with the research literature. This implies that, in carrying out our case studies, we have extrapolated principles such as learning from experience and reflection, which are now central to much thinking about teachers' professional development, to our own development as teacher educators and researchers.

\section{Design of the study}

The central research question driving our study is: What central principles shape teacher education programs and practices in ways that are responsive to the expectations, needs and practices of teacher educators and student teachers? Our search for responses to this question was driven by an underlying concern for teacher education to be meaningful and valuable for student teachers and teacher educators alike. Hence ecological validity was an important criterion that shaped our study. It required us to build our study on realistic examples from efforts to improve teacher education. Moreover, we suggest that the development of a shared professional language among teacher educators and researchers (Loughran, 2006) is a prerequisite for developing a knowledge base on which to build teacher education practices in different settings and countries. Thus it seemed important for us to move beyond specific contexts and cultures to the crosscultural approach adopted for this study.

Three cases from different continents were analyzed: programs at the IVLOS Institute of Education at Utrecht University, The Netherlands, at the Faculty of Education at Queen's University, Canada and at the Faculty of Education at Monash University, Australia. By analyzing programs at which the authors work, we were able to provide insider perspectives. The three programs lend themselves to comparison because they share general structures. In all three, the end-on model (post-graduate teacher preparation) has been the major program structure for a considerable period of time. While there have been minor variations in the structure of these programs over time, all three share the familiar organizational features of curriculum method subjects and educational foundational subjects, with school teaching experience (practicum) constructed as the real world site for applying "university education to school teaching practice." In many ways then, each of these programs carries the stereotypical structure of a traditional teacher education program that has attracted so much scrutiny and criticism in recent years. Hence, the fact that the research program underpinning this paper is drawn from such 
program structures offers real opportunities for abstracting these principles to teacher education more generally.

All three programs have been the objects of many previous research studies. We elected not to collect new raw data, but to carry out a meta-analyis of these documented research studies (Brouwer \& Korthagen, 2005; Hermans, Créton, \& Korthagen, 1993; Kessels \& Korthagen, 1996; Koetsier \& Wubbels, 1995; Koetsier, Wubbels, \& Korthagen, 1997; Korthagen, 1985; Korthagen \& Kessels, 1999; Korthagen \& Russell, 1995; Korthagen et al., 2001; Loughran, 1996, 1997, 2002; Loughran \& Russell, 1997; Northfield \& Gunstone, 1983, 1997; Russell, 1995, 2002; Upitis, 2000; Vedder, 1984; Vedder \& Bannink, 1987). We also used different kinds of program documents in order to extract ongoing principles and features underlying the programs. The criteria for including a principle were:

1. that on the basis of the materials under study, it was evident that the staff of the teacher education program consider the principle to be fundamental, in the sense that without this principle the program would lose its essential nature;

2. that the principle could not be considered as selfevident (such as "having students study textbooks") or in any sense "normal." Rather, the principle should differentiate the approach followed in the program from several others in the world;

3. that the principle could be recognized in many practices throughout the entire program.

While searching for these underlying principles, we also focused on paradigmatic examples (a term used by Freudenthal, 1978) of good practice, i.e., program elements that are representative of several of the important characteristics of a program. When we present our findings below, these paradigmatic examples help to clarify and support the principles we derived from the three cases in this paper. Thus, for each principle, we describe a paradigmatic example to allow the reader to understand more fully the concrete meaning of the principles and to check their ecological validity. Moreover, we believe the examples are helpful in moving beyond the individual context of the cases to a broader more generalizable situation. In this respect we follow the guideline of naturalistic generalizability (Stake \& Trumbull, 1982), whereby rich descriptions of contexts are crucial so that others can draw analogies to their own situations (see also Stevenson, 1996). In addition, we wish to contribute to what Lather (1991) calls catalytic validity, i.e., the degree to which the research can lead to transformations of practice (see also Zeichner \& Noffke, 2001).

Through ongoing framing and reframing (Schön, 1983) of our situations, through exchanges of email, face-to-face meetings, and workshops and conference presentations, we challenged each other to sharpen assumptions and present evidence for the principles that we derived, grounded in the cases and in theoretical frameworks in the professional literature (based on the notion of dialogic validity, Anderson, Herr, \& Nihlen, 1994). This procedure included weighting the credibility of alternative interpretations and considering patterns in the cases (pattern matching, Merriam, 1998).

Our methodology conforms to familiar approaches to teacher research (Cochran-Smith \& Lytle, 1993; Zeichner \& Gore, 1995) and self-study (Hamilton, 1998; LaBoskey, 2004), i.e., types of research in which analyses of the tensions, dilemmas and problems of practice (Berry, 2004) directly influence the improvement of this practice. Hence our approach draws on notions of reflective practice (Bode, 1940; Boud, Keogh, \& Walker, 1985; Dewey, 1933; Schön, 1983, 1987), but it also extends some of the initial approaches to individual knowledge of teaching about teaching that were developed through the reflective practice movement of the late 1980s and early 1990s (e.g., Calderhead \& Gates, 1993; Clift, Houston, \& Pugach, 1990; Grimmett \& Erickson, 1988; Osterman \& Kottkamp, 1993). We are therefore purposefully attempting to push this knowledge base beyond the individual so that a shared language of practice is more accessible and more directly applicable across contexts and therefore to teacher education programs more generally.

One final measure also strengthened our study. We did not carry out our task as an isolated group of three teacher educators from three different parts of the world, but we have broadened our study, first by means of an interactive symposium at the 2001 meeting of AERA, and secondly, by creating a website on which questions collected from the symposium audience formed the basis of an on-going discussion. This paper seeks to extend the discussion to the broader AERA community and to begin to create a basis for an understanding of the value of considering teacher education as being constructed on foundations of learning to teach in ways that 
might be articulated through what we have come to term principles of practice.

\section{General description of the programs and program change}

In this section, we briefly outline the general features of the three programs, as well as trends in changes within these programs.

At Queen's University in Canada, the traditional nature and timing of the practicum was challenged by introducing an early extended practicum that initially spanned 14 of the first 16 weeks that make up the first term (Fall) and with the practicum beginning on the first day of the school year. Although the practicum now begins 4 weeks into the school year, candidates continue to be placed in cohorts (generally 4-10 per school) and supervised by a Faculty Liaison who works across all subjects and grade levels. This major change in structure was intended to shift the focus of professional development from learning in university classrooms to learning from firsthand experience. Upitis (2000) provides a detailed account of the rationales for program consequences and the issues that arose in the first year.

Among faculty, the change in program structure has challenged two assumptions that were embedded in the structure followed for almost 30 years and virtually taken for granted:

1. Those learning to teach can readily translate what they are told into practice.

2. Supervision of those learning to teach should focus on the subject being taught rather than on the overall process of professional learning.

The structural changes in the program have paid rich and complex dividends by highlighting and focusing attention on how teacher educators think about their work. No one publicly anticipated the extent to which changes in structure would generate intense pressures on individuals' longstanding pedagogical practices. The pressure on professional belief systems followed the pressure on practices, and several basic questions continue to serve as points of on-going discussion among those who teach in the program:

1. How, if at all, should one's teaching change when teacher candidates have much greater depth of teaching experience?
2. Is it appropriate for secondary candidates to be supervised by individuals who are not experts in the subject the candidate is teaching?

At Utrecht University in the Netherlands, the teacher preparation program has been developed in close cooperation with school administrators and mentor teachers and is built around two main teaching practice periods. The first is a 4-month period in which the student teachers go to the schools in closely collaborating triads and gradually start to teach whole classes. Regularly, they come back to the institute for group discussions and inquiry about their teaching and reflection on their practice. After a 2-month period at the institute, devoted to workshops on specific educational issues, further reflection, a small research project and theory based on the experiences in the teaching practice period, the Final Individual Teaching Practice Period begins. During 4 months the student teacher gains full responsibility for several classes and is supervised at a distance by the mentor teacher, who does not visit the lessons. This means that the supervision draws heavily on the student's experiences and reflections.

The Utrecht program has seen gradual changes over the last two decades, as more and more program elements were improved, often as a result of research into their effectiveness. However, the underlying rationale has remained the same, which is that it is important in teacher education to continuously commute between practice and theory (for details, see Korthagen et al., 2001). Reflection is seen as the essential tool for linking practice and theory, and from the very start of the program there is strong focus on systematic reflection. This means not only that the student teachers are stimulated to reflect because their supervisors continuously ask them stimulating questions, but also that considerable emphasis is put on learning how to reflect in a structured manner, on your own or together with peers.

More recently, new program structures have been introduced, alongside the original program, especially programs in which people from other professions wanting to become teachers receive tailor-made guidance. As these new programs have not yet been the objects of empirical research, we do not include them in this study.

At Monash University in Australia, the traditional Graduate Diploma of Education (a 1-year end-on course) has been supplemented by the 
introduction of double-degree programs (B.A./ B.Ed. and B.Sc./B.Ed.). An economic need to rationalize teaching across the traditional 1-year end-on program and the double-degree programs meant that less attention was paid to the reasons for the specific structures of these programs and to the particular needs of the student teachers within each program. Student teachers came to be viewed as the same, regardless of program enrollment. Rationalization pressures have severed earlier links between research on teaching and on learning about teaching, on the one hand, and the program's structure and purpose, on the other. Where once decisions about program structure were based on understandings of teaching and learning about teaching that were responsive to the needs of student teachers, and where once the research and practice were supported in meaningful and valuable ways, teacher educators began to retreat to the safety of their own classrooms, a response that many teacher educators will no doubt recognize. This retreat into the private world of the classroom comes at a cost, as teacher educators' concerns for their personal groups of student teachers overshadow the program as a whole. Thus program coherence is easily diminished as the reasons for particular organizational and pedagogical structures tend to be forgotten and an institutional amnesia develops.

The contexts of these three programs share similarities to many others around the world and thus we believe that our analysis of these three cases allows us to arrive at principles applicable to other contexts. On the other hand, the three cases are special in the sense that they have been documented and researched for many years, offering us solid ground for analyzing the cases. Moreover, in all three cases the issue of learning from practice has been a central point of attention for many years. The teacher educators in the three programs share the assertion that one does not learn through experience, but through reflection on experience and through interaction with others. Hence, for both the educators' teaching and the student teachers' learning, reflection and intercollegially supported learning are viewed as important cornerstones of practice.

This emphasis on reflection and intercollegially supported learning expresses a process view of learning and knowledge, not a product view of knowledge. Theory added to student teachers' reflections is built as much as possible around their experiences, questions and concerns. Moreover, much of the theory is not so much of a conceptual nature, but is tailored to the specific situation under consideration and has the characteristics of phronesis (Kessels \& Korthagen, 1996), which means that it focuses on developing awareness of those characteristics of specific types of situations that are important to the question of how to act in such situations. Phronesis can be seen as the opposite of episteme, which is generalized knowledge about many situations and which aims at understanding these situations. Phronesis involves awareness of factors that are not of a solely cognitive nature: it implies sensitivity to the feelings of the participants in the situation and to relational aspects, and it implies a commitment to certain values embedded in the situation. Phronesis is thus relevant both to the teacher educators' practices and to the practices of their student teachers. This implies a synergy of teaching and learning that is crucial to our understanding of teacher education and a foundational aspect of the principles that we outline in the next section.

\section{Principles for change in teacher education programs and practices}

From our ongoing analyses of the three cases of pre-service teacher education and our three-way conversations about the interpretation of these cases, we have constructed seven principles of student teacher learning and program change in teacher education that we see as fundamental. At the heart of the intention of reflective practice is the development of the role of experience in pre-service teacher education as a central plank of all three programs considered in this study and, as such, learning from experience is critical in shaping the following principles. Below we describe these principles and illustrate them with examples from practice, translating these paradigmatic examples into vignettes.

\section{Principle 1: Learning about teaching involves continuously conflicting and competing demands}

Teacher education is inevitably inadequate (Northfield \& Gunstone, 1997) and cannot fully prepare teachers for their entire careers. This suggests to us that teacher preparation needs to focus on how to learn from experience and on how to build professional knowledge. In so doing, there is a need to respond to a range of conflicting and 
competing demands. The following vignette illustrates how these competing demands can be meaningfully used to help student teachers learn from their experiences in ways that might help to shape their thinking about their teaching. It is an excerpt from a reflective report by two student teachers at Monash University.

In EDF 3002 [a third-year subject], we form small teams [of three or four student teachers] to teach something to our peers for about $45 \mathrm{~min}$ and it is video-taped. We are responsible for debriefing that experience, getting written feedback from the class and then, after watching the video, writing up what we learnt through the experience.

In my team, we decided to do some group work. I thought from the start that our lesson would engage the class, promote collaborative thinking and point out new ways of looking at the issue of cloning. By each of us moderating a group, I felt we would be able to keep people on track and produce a more meaningful contribution for everyone. I am now a little concerned that we restricted our learners too much through our constant presence-I mean how much structure is too much?

We wanted to do group work because of what the group did in last week's class. In their group work they just walked from group to group in a way which I found unhelpful because it seemed superficial and they didn't really question us and when we did it was just, "how are you going" and of course we replied, "OK." I thought, "How can you control what groups are talking about if you only spend a couple of minutes with them?"

While I listened in my group last week I didn't contribute so I wanted my group this week to voice an opinion regardless and if we were in each group then we could control the discussion and get everyone to talk and learn what we wanted them to learn. However, the discussion at the end left me wondering whether anything had actually been learnt by the learners. Was what occurred a group sharing of information and knowledge on different points of view on cloning, or was it just a superficial glossing over? So for the moment I am still pondering what constitutes good and bad learning and teaching (Extracts from reflective report by Angela and Michael, Monash University).
This vignette highlights the value of students struggling with the need to simultaneously be both learners of learning and learners of teaching so that they come to better understand not only how a particular teaching approach influences their learning, but also how that teaching was constructed and performed. Clearly, what they experience as learners of teaching dramatically shapes their views of practice. Therefore, modeling approaches that create opportunities for student teachers to be cognizant of their learning about learning and their learning about teaching need continually to be made explicit.

Similarly, a student teacher's learning (how powerful, useful, and meaningful it is to them) and its relationship to the teaching that created (or inhibited) that learning need to be specifically linked to the learning of their students when they are in the role of teacher. For although student teachers may not have experienced meaningful learning when a particular teaching approach was used, they may well believe that their students will experience it differently when they are the teacher. This was pointed out by Lortie (1975) as the apprenticeship of observation. Hence student teachers may subconsciously discount their own learning experiences when they become the teacher and fail to see that their students' experiences as learners in a particular situation may well be the same as what they experienced under comparable circumstances. Alternatively, they may attempt to do something about it and assume that by making easy changes in teaching, changes in learning will naturally follow:

One thing I remember when I was a student in class was that it had always looked so much easier when someone else was doing it... Teaching is a lot more complex than standing out the front talking... I need to listen to my students (Denise, post-teaching practicum response, Monash University).

When a student teacher such as Denise develops this insight, the next competing demand she may encounter is that between her wish to really listen to the students and the need to keep control over the entire classroom. She will only learn how to deal with this dilemma if she gets sufficient relevant experiences, both as a learner and as a teacher, and if, in relation to these experiences, the teacher educator demonstrates alternative perspectives and approaches to practice. 
In sum, the development of practice in light of competing demands requires an approach that revolves around the need to create meaningful collaboration in learning and teaching, collaboration of peers and collaboration of teacher educators and student teachers. Teacher education practices that support the search for "the recipe" for how to teach or that make it appear as though teaching is simple and unproblematic reduce the impact of the conflicting demands associated with learning to teach. Consequently, not paying attention to the assertion above may lead to teacher education practices that inadvertently encourage student teachers to search for the right way to deliver information in spite of their experiences to the contrary. Helping student teachers recognize and respond to the competing demands in their learning to teach is one way of helping them to learn in meaningful ways through experience. In traditional 'theory-into-practice' approaches to teacher education this seems to have been overlooked and it may well explain the phenomenon of the reality shock in graduates. For if - as a teacher education studentyou start to believe that teaching is about translating theory into practice in a direct manner, the confrontation with the complexities of practice is shocking. Beginning teachers very soon discover that they are not the only ones struggling so much with everyday problems in their classrooms. As Elliot (1991) explains, the only way out of the feeling of always falling short is to adapt to the common habit of teachers to consider teacher education too theoretical and useless. Then they can no longer be 'blamed' for not functioning according to the theoretical insights. Elliot (1991, p. 47) concludes:

The perceived gap between theory and practice originates not so much from demonstrable mismatches between ideal and practice but from the experience of being held accountable for them.

This also clarifies how the second principle is linked to the problems stated in our introductory section.

\section{Principle 2: Learning about teaching requires a view of knowledge as a subject to be created rather than as a created subject}

The doctrine that teaching is telling has deeply influenced both teachers and teacher educators. The idea that teachers are to be taught the results of research carried out by researchers (who are not seen as teachers) helps to account for the widespread sense of irrelevance of courses in schools of education (Russell, 1999, p. 234). It also promotes the conviction that experience is largely irrelevant to learning and that experience actually hampers the development of more effective ways of learning and teaching in schools. All three of our cases show attempts to develop a more process-oriented view of knowledge and to break with traditional ways to introduce theory into teacher education programs. The cases clarify that what is important is not only a change in the choice of theory that is relevant to teachers, but also a change in the nature of theory in teacher education and in the way it is developed in teachers. As Freudenthal (1978) states, the traditional view is one of "knowledge as a created subject" (p. 72), that is, created by others. Freudenthal advocates a view of knowledge as a subject to be created by the learners themselves, by a process of guided reinvention. For teacher education this has at least three advantages.

1. The kind of theory resulting from student teachers' own reflections on practical problems is much more linked to their own situations and concerns, and thus has much greater emotional significance for them.

2. Student teachers get used to the process of learning to develop such knowledge, which provides them with a capacity for ongoing professional growth during their careers as teachers.

3. In this way teachers are prepared to take a different approach to theory in their teaching of students in schools.

This second principle for the pedagogy of teacher education lies at the heart of what it means to teach the students, and not the curriculum principle 3). Its consequence is that teacher educators should actively create situations that elicit the wish for self-directed theory building in their students. Moreover, teacher educators must be able to foster group processes in which student teachers together work on the creation of their own theories of teaching, for example, through intercollegially supported learning (see principle 5).

An example of a representative program element is the one-to-one (Vedder, 1984). It is part of the Utrecht undergraduate orientation course that prepares students interested in following the post-graduate teacher education program. It has 
been developed in response to the problem that teaching a whole class on a regular basis appears to be a complex experience for beginning student teachers, an experience that tends to foster concerns for survival without the atmosphere of safety necessary to a balanced learning process. Moreover, during periods of classroom teaching, student teachers rapidly begin to focus on classroom management rather than on the learning of their students. This is why the first teaching practice period has been simplified as follows.

Each prospective teacher gives a one-hour lesson to one high school student once a week for eight weeks. Neither the university supervisor nor the cooperating teacher is present during the actual one-to-one lessons, but there are supervision sessions and seminar meetings during the oneto-one period. The lessons are audio-recorded, and are subsequently the object of detailed reflection by the student teacher. This reflection is structured by means of the ALACT model (named after the first letters of the five phases, see Korthagen et al., 2001 and Fig. 1).

For the one-to-one teaching experience, the phases of the ALACT model are translated into standard questions, which are addressed by the student in a personal logbook. These include such questions as:

1. What did you expect and how did you prepare for it? (phase 4 of the ALACT model)

2. What actually happened? (start of phase 2)

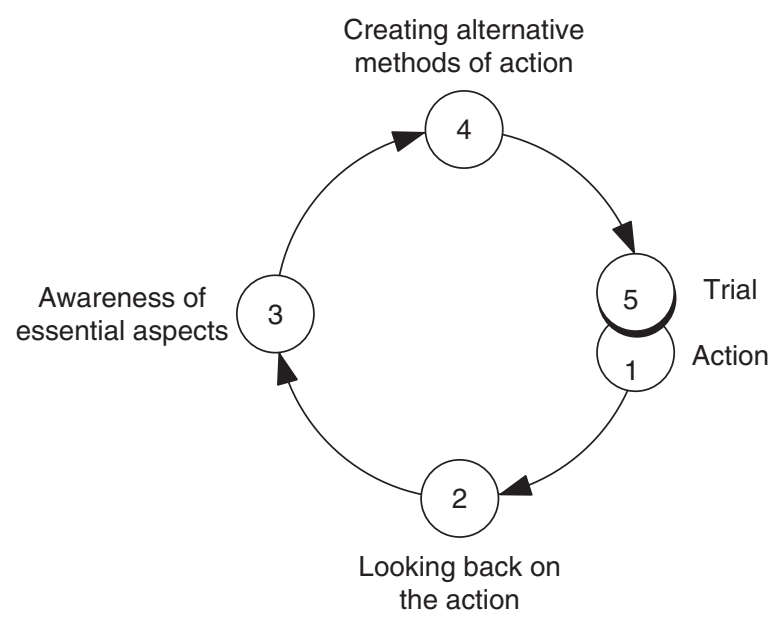

Fig. 1. The ALACT model describing the intended process of reflection.
3. Choose some episodes from the tape and describe what you did and what the student did, what you thought and felt, and what you think the student thought and felt, and how these aspects influenced each other (concretizing phase 2).

4. Try to derive conclusions from this (phase 3).

5. Formulate your intentions for the next lesson (phase 4).

The third question is often the most crucial one, as it focuses on the details of the lesson.

During the one-to-one period, the student teachers form pairs. Of the eight one-to-one lessons, four are discussed by the student teachers in these pairs, and four lessons are discussed by the pair and the supervising teacher educator. The university supervisor can thus offer small theoretical notions fitting in with the process the student teacher is going through (phronesis). After both types of discussion the student teacher writes a report with the most important conclusions.

Vedder (1984), who studied the effects of the oneto-one arrangement, distinguishes two main types of effect. The first has to do with the development of practical skills, which appears to be promoted by the link that has been created between theory and practice. The second is related to the promotion of reflection. A major advantage of the one-to-one arrangement appears to be that it focuses the student teacher's attention on the learning process of a single student, instead of on the issue of maintaining classroom order (Vedder \& Bannink, 1987, p. 10). At the same time, the student teachers appear to become aware of their own learning processes, as documented in their logbooks. (This is a specific point of attention at the end of the one-to-one period.)

A general finding is that by listening to the audiorecordings, the student teachers rapidly find out that they failed to listen to what the student was saying, or started an explanation before the problem was clear to the student. As one of the Utrecht student teachers put it: "The one-to-one caused a shift in my thinking about teaching, from a teacher perspective to a student perspective." This quote is representative for the learning processes of most student teachers in the one-toone. However, there also appear to be considerable differences between student teachers in what is learnt during such a one-to-one arrangement. 
To mention some examples, one student teacher focused on the lack of self-confidence in the student she worked with, and started a search for ways of improving the child's self-image, while another student teacher was confronted with her tendency to explain things at a fairly abstract level. She developed the wish to include more concrete examples.

In summary, the one-to-one gives student teachers many opportunities to learn on the basis of their own experiences and the concerns they develop through these experiences. They learn not so much by being taught by their teacher educators, but by structured reflection on their experiences and discussions with peers. In this way the student teachers begin to create their own professional knowledge.

\section{Principle 3: Learning about teaching requires a shift in focus from the curriculum to the learner}

Consider the following excerpts from a student teacher's logbook:

From my perspective, my contribution to the teaching episode did not achieve what I wanted it to achieve. However, I take solace in the fact that I believe that it was a valuable lesson in what not to do and in my belief that others might benefit from my mistakes.

Shortly after I placed the transparency on the overhead projector I witnessed blank disinterested faces staring at the screen... I witnessed large blocks of small print on an overhead that does absolutely nothing to engage the learner. The amazing thing that accompanied my realisation was that I did absolutely nothing to remedy the situation. I soldiered on completely aware of the situation, but unable to think of a way to get myself out of it... I would never present information to High School students in this manner. Why did I do it in this situation? Ultimately, good teaching practices are good teaching practices, no matter who you are teaching (Extracts from reflective report by Elaine, EDF3002, Monash).

Elaine illustrates how actions sometimes defy belief. She knew what was happening yet she could do nothing about it, continuing to act in a manner that she believed to be inappropriate. This vignette highlights an important issue in learning about teaching: it is crucial that student teachers have opportunities to access the thoughts and actions of teachers in ways that help to illuminate not only the teaching actions themselves, but also the feelings and the reasons for particular teaching actions.

To fully illuminate the dynamics of a teaching situation, student teachers need opportunities to understand what is involved in planning the teaching, doing the teaching, and reflecting on the teaching. Then they need to link all of these to the relationship between the teaching and the concurrent learning. One way of creating such opportunities is by helping student teachers to experience teaching practice being both constructed and deconstructed - and for them to be central to the process - so that their learning about teaching is embedded in their experiences of learning and teaching (Segall, 2002).

A common view of learning to teach includes the assumption that the university-based components of teacher preparation offer the theoretical underpinnings of teaching and that school teaching experience (practicum) offers a situation in which those previously learning principles of teaching are practiced. This view creates many difficulties, including the fact that the "expertise" of teaching practice is often assumed to reside largely in schools with teachers. This view diminishes the rich possibilities that can be made available at the university site.

One way to reframe this situation involves constructing appropriate ways for student teachers to genuinely engage in experiencing the various aspects of teaching in an environment where such engagement is the focus, rather than in an environment where successful teaching and controlling students are the dominant concerns. In so doing, moving out into the school practicum experience might then be more meaningful and informing. However, for many student teachers this is difficult because they have a real need to develop some of the skills of teaching (questioning, wait-time, listening, structuring content, timing) and to become competent at them before a focus on learning-by-teaching can readily be grasped and responded to. When we construct teacher education programs that are driven by curriculum, this difficulty is simply exacerbated.

"Telling is not teaching, listening is not learning," is a message that must be embedded in experience and constantly revisited if it is to have real meaning for practice. Thus there is a constant need to "not tell the class" about an issue (in the teaching 
situation), but to make the issue a part of the teaching episode. This goes to the heart of what it means to teach the students, not the curriculum and to the heart of the problem, stated in the introduction, of linking practical experiences and theory. The learning of student teachers is only meaningful and powerful when it is embedded in the experience of learning to teach. As teacher educators we need to be actively creating situations where this can occur and for it to be a natural part of teacher preparation. Teaching a curriculum of presentation skills, questioning or interpretive discussions is very different from embedding student teachers' learning in ways that enable them to experience the "doing" of the curriculum more than the information of the curriculum. This is at the heart of the dilemma that teacher educators constantly face yet seldom address, in what Myers (2002) describes as constant reliance on telling, showing, and guided practice. If the telling, showing and guided practice approach is to be displaced, there is a need to reconceptualize teaching about teaching in terms of teaching the students, not the curriculum. A subtle, but important reformulation is that this means helping student teachers learn how to teach, i.e., helping them to learn how to help children learn.

\section{Principle 4: Learning about teaching is enhanced through (student) teacher research}

Following directly from the previous principle is the need to trust that student teachers can and should research their own practice. Student teachers are emerging professionals who are capable of directing their own professional development by researching their own teaching. By creating and sharing their understanding of practice through the results of their own research, perceived distinctions between theory, practice, transmission of knowledge and socialization into teaching may be confronted and their professional roles may be better recognized, defined and enhanced.

Student teachers encounter many new and perplexing experiences during their practicum placements. This substantial range of experiences can be viewed as data from which they might become more informed about their own development as teachers. Therefore, actively researching their own practice can be a catalyst for student teachers to come to "see differently," to reframe a situation (Schön, 1983, 1987), and to thereby gain insights into how they might come to better understand that situation and act within it. This is in stark contrast to highlighting a particular problem and telling student teachers what it is they should know or learn from that situation. For example, student teachers (and, for that matter, many experienced teachers and teacher educators) often struggle with interpretive discussions (Baird \& Northfield, 1992; Barnes, 1975). If student teachers can create a situation where they physically force themselves to wait rather than rush in to fill the gap in a discussion, they can experience what it might be like if students are given time to think and respond thoughtfully rather than play "guess what's in the teacher's head." One way to create opportunities for student teachers to begin to research their teaching and to begin to see things differently involves the development of anecdotes (van Manen, 1999), as used in the Monash program (see Loughran, 1997, 2002). These can be viewed as opportunities for student teachers to collect data and develop understanding through framing and reframing on a small, but critical, scale. By encouraging episodes to be reconsidered, developed and articulated through the writing of anecdotes, the meaning derived from situations can unsettle some of their taken for granted assumptions about teaching (Brookfield, 1995) and increase the likelihood that new ways of seeing will emerge.

If teacher education programs genuinely focus on the student teacher as learner, then it is the ability to analyze and make meaning from their experiences that matters most; this contrasts starkly with settings in which the teacher educator filters, develops and shares knowledge with student teachers. The central distinction here is that the knowledge developed by student teachers researching their own practice may not necessarily be new to teacher educators, but the process of developing the knowledge is dramatically different when student teachers are responsible for its development. Who is doing the learning is what really matters. For example, when student teachers are given permission to collect and analyze their own data from their own experiences during a practicum, the subsequent assertions about practice (see Table 1) are qualitatively different in value and meaning from when similar assertions are passed on to them by a teacher educator. This difference extends further when student teachers document and share these assertions with their peers because their sense of ownership is based on drawing on their experiences in order to learn from those experiences. This can lead 
Table 1

Examples of student teachers' assertions about practice

- The medium of instruction influences the success (or failure) of the lesson.

- Sometimes you teach in ways you do not like because it helps you cope.

- Too much enthusiasm (student and teacher) may lead to other problems.

- Students may have more control over what works in the classroom than the teacher has.

- The success of teaching strategies is dependent on students' skills and students may or may not have those skills.

to recognition of new ways of seeing the practice setting.

The assertions in Table 1 represent important transitions in thinking by student teachers and powerful ways of their informing their own practice, making such learning meaningful and useful and offering them interesting insights into practice as a result of framing and reframing. Learning by researching their own practice is therefore a crucial component in learning about teaching and in teaching about teaching, and another means of counterbalancing the tendency in traditional teacher education to create a gap between research-based knowledge and practice.

Alternative approach:

Student-Directed Learning: Cutting the Puppet Strings:

Teacher as Researcher assignment (4th year, double degree, Monash)

I like organisation. I schedule my life into halfhour blocks, and then fill them. I like to feel in control. I like waking up knowing exactly how the day will pan out. Unpredictable events in the daily schedule are good for dramatic re-tellings with friends, but they aren't known for their productivity. If I forget to do something, or a scheduled event runs over time, I kick myself for not being prepared.

This is reflected in my teaching practice. If I am not in control, I tend to be insecure, edgy and without focus. My last teaching round was the very picture of control and cohesion. Preparation for class was completed early. I could explain exactly where the class was going to get to by the end of the period. It was calm, complete and predictable. If anything that didn't appear in my lesson plan occurred, it was swiftly ignored and the group was re-focussed. I could fall back to the detailed script, assured that if we stuck to the middle of the road we would all be happy at the end of the lesson. But too many times there was random mutation. New ideas! New interpreta- tions! Unforeseen areas of fascination! Activities shifting focus. They were learning, it was still relevant, but I was pushing them into what was perhaps a restrictive and narrow pathway. I subconsciously wanted them to focus on what I wanted them to think about, not what they wanted to think about.

In this project, the idea of a student-focused learning environment will be analysed and examined. In this case, I attempted to give a Year 9 English class the opportunity to experience a student-focused learning environment. I hoped to create a student-focused learning environment by handing over as much of the decision-making to the students as possible. My journey is documented in my journal and lesson plans, from which the analysis that follows is drawn... The most important outcome for me was an increased awareness of the way I teach. I am now convinced that students need to be active, or more active, in their learning environment. If teachers make too many decisions on behalf of the students, it becomes highly unbalanced and much more like work. The same results, or the same outcomes, can be achieved by "making it new." If the teacher is able to move and grow with the students, then they are much more likely to begin to own their learning. They are responsible for it; teachers are only there to support, guide and instruct when it gets too tough. There are many instances in schooling where direct instruction and formalised criteria are beneficial. But having watched these students grasp their challenges and solve their problems, I have become increasingly aware of the students having individual needs. Everyone is different, with different skills and ways of thinking. If we cut the strings, they are given more of an opportunity to create, grow and mature as learners. But they should feel safe in the knowledge that their teacher is there to help and support when they need it... If the students were 
given too much ownership of their learning, then some would not move on at all. Others may move in a direction which really isn't that productive, as it is in a direction they are familiar with or feel safe doing. Students often don't go for the most challenging idea or journey. They need to be given encouragement and support to do this, and a few gentle nudges in the right direction do not go astray... The education of people, not just children, should be approached with an open mind. The teacher's way is not always the best way. The teacher should learn as much in the class as the students do. The puppets do need a few strings attached, but should be given the opportunity to perform on their own as often as possible. The puppeteer should not cut all the strings. Just have the scissors handy, and be aware of each student's individual journey (Student-teacher research report, Monash).

\section{Principle 5: Learning about teaching requires an emphasis on those learning to teach working closely with their peers}

As Putnam and Borko (1997, p. 1247) state: "Just as students need to learn new ways of reasoning, communicating, and thinking, and to acquire dispositions of inquiry and sense-making through their participation in classroom discourse communities, teachers need to construct their complex new roles and ways of thinking about their teaching practice within the context of supportive learning communities." This view concurs with McIntyre and Hagger (1992), who report that "collegiality has been demonstrated to be a critical factor in helping individual teachers to develop their classroom practice" (p. 276).

In the restructured pre-service program at Queen's University, teacher candidates are deliberately assigned to teachers in Associate Schools where they are expected to meet weekly as a school cohort group. Arranging meetings within the school day is more than a matter of finding gaps in the timetable, for some experienced teachers are reluctant to see any time taken away from the act of teaching. Similarly, some teacher candidates are puzzled about why they are meeting when they could be teaching. Those who find it difficult to stand back from experience and look for patterns in accounts of teaching experience are often those who also find reasons to be absent from meetings or to arrive late and leave early.
During the first 5 years of the restructured program at Queen's, differences across schools and among cohort groups have been striking yet never surprising. Despite the new intention of deliberately fostering working closely with one's peers, the results have usually not approached that intention, as the following illustrates:

In one school to which only four teacher candidates were assigned, it was impossible for the four to arrange a time to meet for two hours once each week. Commitments to coaching teams before and after school and to providing one-onone tutoring during lunch periods became major excuses for never even attempting to work more closely with one's peers.

When teacher candidates do arrange to meet, the sheer novelty and unfamiliarity of such meetings can overwhelm the opportunity to explore the potential benefits of working closely with one's peers. The norm of most prior schooling experiences has been that students are to work independently and be assessed independently as well. The ways in which the university succeeds or fails in providing initial structures and goals for in-school cohort meetings also affects the opportunity to learn about working closely with peers.

The Faculty Liaison assigned to a school and its cohort group has the potential to support peers working closely, if that individual is prepared to act on programmatic intentions. In reality, many individuals assigned as Faculty Liaisons are adjunct faculty members with little or no reason to feel a personal investment in enacting a goal that differs from the familiar norms of schools and universities. In addition, the timing of the Faculty Liaison's visits to the school may or may not fit with scheduled cohort meetings in that school.

The early commitment or lack of commitment shown by one or two teacher candidates within a cohort group can have a major effect on opportunities to work closely with one's peers. The unwillingness of one or two individuals to take group meetings seriously can rapidly undermine the prospects of successful meetings over the 10 weeks of the practicum placement. In sharp contrast, the early, active, and dynamic commitment of two individuals in a cohort group of six can produce highly effective experiences of working with one's peers. When one teacher 
candidate took it for granted that everyone would meet once a week and then ensured that a meeting room was reserved and an agenda distributed well in advance, the members of the group became the major source of support for each other, readily enriching the support provided by associate teachers or the Faculty Liaison.

When the Faculty Liaison responsible for a particular school group is attentive to the process of learning to teach, weekly meetings can provide unique opportunities to develop perspectives on learning to teach. Typically, it is but a few short steps from patterns in learning to teach to patterns in how students are learning to learn. When a restructured teacher education program deliberately emphasizes working with one's peers, the stage is also set for peer learning about teaching to continue into a teacher's career.

Isolation of the individual teacher in his or her classroom is one of the most fundamental features of teaching. Although they may not think about it, students are as aware as teachers that it is rare indeed to see two teachers at work in the same room at the same time. How teachers work with each other outside the classroom is well beyond virtually every student's experience. Thus new teachers arrive with an expectation that their learning about teaching in a pre-service program will be an individual affair, perhaps even a lonely one. When teacher candidates are assigned to individual experienced teachers for their practicum, they may have little opportunity to work closely with their peers. Only on the return to the university are they able to share experiences and explore patterns in learning about teaching from experience, and often this learning will occur in the corridors and coffee shops rather than in their classrooms.

To argue that learning about teaching requires an emphasis on working closely with one's peers is thus an exercise in challenging the culture of the school (or university) as an organization. The challenge is clearly a substantial one, but if the norm of teachers collaborating in learning about teaching is ever to change, we contend that the change must begin in the pre-service program.

For this reason, in the Utrecht program a structure named peer-supported learning has been introduced (Tigchelaar \& Melief, 2000). It is now used in every cohort group, with very positive results. Within the setting of a whole group of student teachers and early in the program, the student teachers are trained in using the ALACT model (Fig. 1), not only for structuring their own reflection, but also to help each other reflect. In small groups of about three, they practice supervision skills aimed at helping each other go through the phases of the ALACT model. During teaching practice periods these groups of three meet on a regular basis for peer-supported learning. Each small group is required to write brief meeting reports in which they both evaluate the process of peer-supported learning and describe the content of their small-group discussion. In the reports, they can also put forward issues on which they wish to receive further support from the teacher educator. Every 2 weeks, there are meetings of the whole cohort group, facilitated by the teacher educator. These group meetings are partly devoted to further training in supervision skills, in order to support and further develop the processes of peer-supported learning. In addition, on the basis of the problems and concerns that formed the content of the supervision sessions in the small groups, themes and issues are discussed in the whole group. This is where the teacher educator again takes the role of supporting the professional development of the student teachers, beyond developing their competency to support each other. The teacher educator can introduce new content based on the issues raised in the reports of the small groups.

Through this structure, a balanced sharing of the responsibility for professional learning is created between the teacher educator and the student teachers. The structure has many advantages. First, it further strengthens the capacity of student teachers to take responsibility for their own learning. An important aim behind the structure is also that it prepares them for peer-supported learning during the rest of their careers, thus creating a counterbalance to what Feiman-Nemser and Floden (1986) see as the highly individualistic and noncollaborative culture of teaching. As one student teacher wrote:

What is more pleasant than being able to tell your own story to people who have as much expertise as you, but who also struggle as much as you do, and who are trying to help you in the expectation that you will be helping them next time? (reflective report by Kristel Peters, Utrecht). 
The process of learning how to support each other's reflection also promotes students' insight into the ALACT model and hence their individual competency for reflection. Another advantage is the fact that, after an initial investment, the structure saves time for the teacher educator. Fellow-students can become valuable supervisors, thus taking over part of the role of the teacher educator. Moreover, through the reports of the small groups, the teacher educator receives concrete information about the learning processes and the concerns and problems that surface with the student teachers. This helps the teacher educator in selecting the topics to be dealt with in the group meetings and increases chances that these topics will be experienced as relevant by the student teachers. Finally, many of the supervision skills the student teachers acquire during their preparation for peer-supported learning are just as important in their guidance of their own students in school.

A new development in recent years involves the use of electronic tools, such as WebCT, to enable the student teachers to communicate by e-mail during their teaching practice periods (Admiraal, Lockhorst, Wubbels, Korthagen, \& Veen, 1998). Especially in cases where the student teachers do their teaching practice in schools far removed from each other, this can be an excellent way to create possibilities for exchange. Moreover, the teacher educator can easily monitor the conversations and, if appropriate, react to them, either to improve the process of peer-supported learning or to support student teachers clearly in need of specific help.

The fifth principle can be reformulated in terms of the need for horizontal rather than vertical relationships in learning to teach (Galesloot, Koetsier, \& Wubbels, 1997): if, in teacher education, students get used to learning in collegial relationships, this will help to bridge the gap between what is done in teacher education and what those learning to teach actually need in their future practice.

\section{Principle 6: Learning about teaching requires meaningful relationships between schools, universities and student teachers}

Building on their experiences in the Monash program, Northfield and Gunstone (1997, p. 49) contend that "Teacher educators should maintain close connections with schools and the teaching profession." The words flow easily from the tongue or the pen, and they just as easily vanish into the realm of good intentions. Before teacher educators can maintain close connections with schools and the profession, they must understand the many intricate ways in which teaching itself is similar to and different from teaching about teaching. Teacher educators also require a practical understanding of the impact of practice on theory and of theory on practice as a sound basis for building "close connections." How easily teacher educators assume that close connections are somehow natural or automatic, especially if the teacher educator has relatively recent experience teaching in a school. As we know, most do not, but in and of itself, that is not the central issue. Close cooperation in the name of supporting learning about teaching requires the ability to hold three different perspectives simultaneously: the perspective of the individual learning to teach, the perspective of the teacher in a school, and the perspective of the teacher educator in the university setting. Not everyone is willing and able to do this.

In the Utrecht program, close co-operation between teachers in the schools, who supervised the student teachers, and university-based teacher educators has been influential during the process of developing the present program structure and has certainly contributed to the integration of theory and practice within this program. Moreover, more than $80 \%$ of the cooperating teachers attended training courses in supervising student teachers, given by teacher educators from Utrecht University. This was facilitated by the fact that for many years the cooperating teachers received time from the Ministry of Education for their task of supporting student teachers' learning. However, when this release time was considerably diminished during the 1990s, this changed the whole picture: cooperating teachers started to skip schooluniversity meetings and the training courses.

The effect of a government decision illustrates a conclusion drawn by Bullough and Kauchak (1997):

Schools and higher education institutions are both very busy places. Unless sufficient resources can be freed to provide opportunities to support the extended conversation needed to create a shared agenda and unless there is a greater commitment to stabilizing participation, separatist partnership patterns will not only persist but predominate (p. 231). 
If we return to the Queen's University experience, we see that while the traditional program structure appeared to give lip service to close cooperation, the reality was that teacher candidates arrived at three different points in the school year, stayed for 3 weeks during which they might be visited once by a faculty member, and departed to return to the university. The routine was familiar, the rationale had long been forgotten, and cooperation was anything, but close. The new program structure provided rich and ample opportunity for all that to change, but there was never the time for schools and university to explore together (cooperatively!) what closer cooperation might mean.

Extensive consultation with focus groups of associate teachers and principals had shown that support for the new structure could be developed, but the nature of innovation carries an inherent contradiction: everyone feels new levels of incompetence because the demands of the new structure are unfamiliar and unpredictable. Working to achieve new levels of cooperation took second place to the demands of arranging places for 600 individuals who would be in schools for 14 weeks rather than the familiar 3 weeks. In sum, the goal of university-school partnership was announced as a significant aspect of developing the new program structure, but there was little understanding of the possible relationship between structure and partnership. Developing Associate Schools that worked with a Faculty Liaison responsible for all the candidates in the cohort assigned to one school seemed a major first step toward partnership but, as noted by Bullough and Kauchak (1997), the required resources as well as the required changes in perspective were dramatically underestimated.

There is one more important aspect. Despite their naturally different perspectives, experienced teachers in schools and teacher educators in universities are accustomed to coming together to talk about the development and progress of the teacher candidate who has moved from university to school in order to gain firsthand experiences of teaching, but they seldom have this conversation together with that teacher. The experience of innovation and change at Queen's University failed to engage teacher candidates themselves in the dialogue about school-university cooperation, and this may be a key element in understanding why the potential for school-university partnership and cooperation has not been realized. During the initial period of
1997-99, most teacher candidates spoke very positively about beginning their teacher education experiences with 14 weeks in schools (introduced by a week-long university orientation and supported by a 2-week return to the university near the midpoint of the 14 weeks of teaching). Yet neither universitybased nor school-based personnel saw those learning to teach as playing a significant role in the development of closer cooperation. Rather, experienced teachers and experienced teacher educators tended to react with their own personal perspectives on whether extensive experience from the first day of school was a productive way to initiate learning how to teach. When some individuals were positive and others were negative, no one had time to consult with those learning to teach.

Ironically, all over the world, candidates' voices are rarely used to ascertain whether their teacher education program achieves its goals. If sustained inquiry and reflection are to be valued and embedded in a teacher education program, as Goodlad (1990) recommends, then candidates' perspectives must be credited. Cook-Sather (2002, p. 3) advances a strong argument for authorizing students' perspectives. She contends that if a constructivist model is adopted and students are actively engaged in their own knowledge construction, then their voices must be attended to in order to provoke a "conceptualization of teaching, learning, and the ways we study them as more collaborative processes."

When we explore the question of what principles shape teacher education programs and practices in ways that are responsive to the expectations, needs and practices of teacher educators and student teachers, it is our conclusion that close cooperation is needed, not only in the sense of school-university partnerships, but also in three-way cooperation among teachers in schools, teacher educators in universities, and those who are learning to teach. While school-university cooperation is often seen as the broad goal, it is easy to overlook the teacher candidate who is passing through the program structure en route to a classroom of her or his own. Ironically, if we were to view the temporarily present teacher candidate as the one with the most to gain from closer cooperation, that goal might be much more readily achieved. The problems that teacher education has faced for a long time may be well due to the fact that this sixth principle has only recently been taken seriously in the organization of teacher education programs. 
Principle 7: Learning about teaching is enhanced when the teaching and learning approaches advocated in the program are modeled by the teacher educators in their own practice

Evidence of the importance of modeling the practices teacher educators advocate comes clearly from Segall's (2002) revealing ethnographic inquiry into the reality of teacher education experiences seen through the perspectives of six teacher candidates in a social studies methods course at a Canadian university. Segall advances the notion of "reading teacher education as text," whereby the program, the interactions that take place within it, and the individuals who participate in those interactions may be seen, understood, and read as texts. Segall's work underscores the challenge that confronts teacher educators in altering deeply held, acculturated views of teaching and learning and the imperative of moving beyond a narrow instrumentalist approach that emphasizes the "how to," the "what works," and the mastering of the "best" teaching methods (Aronowitz \& Giroux, 1985, cited in Segall, p. 13). Segall contends that unless this alteration of deeply held views occurs, prospective teachers will be unable to recognize and challenge their assumptions, talk to their school experiences, consider alternatives, and contextualize theory within practice and practice within theory. It is Segall's conclusion that they will fall short of the goals most commonly cited by teacher educators for those future teachers who are expected to transform teaching practices in schools and work for social justice.

The contradictions persist between theory and practice within teacher education institutions and, in many respects, little progress has been made through several generations of rhetoric about teacher education reform. Taken even further, the issue is captured in the following assertion: "Universities generally, and university-based teacher educators particularly, have no right to recommend to teachers any teaching practices that they have not themselves used successfully at the university" (Russell, 1999, p. 220). So long as teacher educators advocate innovative practices that they do not model, illustrate, and read as text in their own teacher education classrooms, teacher education reform will continue to elude us.

Student teachers report their disappointment when they experience a class in which a lecture is used to present alternatives to the lecture method.
Learning about ways in which experienced teachers and teacher educators take risks and develop new teaching approaches is one way for new teachers to understand when and how it is possible and essential to take professional risks. For example, in the Monash program, student teachers are offered the opportunity to critique their teachers' teaching and to discuss the pedagogical reasoning (from the teacher's perspective) that underpins different teaching episodes. This has been reported in detail by Berry and Loughran (2002); however, we offer the following as a brief insight into students' understanding of such situations.

I [Berry] began to reflect on the delicate balance between exposing our vulnerability as teacher educators and maintaining students' confidence in our position as leaders. I recalled instances when John [Loughran] had struggled with decisions about how to debrief students after particularly risky interventions. Now I was beginning to better understand and feel that myself - through experience. At the same time, student experiences were strong:

Student 1: You gave us an opportunity to see how a student's interpretation of a teacher's actions is not always synonymous with teacher's interpretation of his or her actions.

Student 2: To examine the disparity in the range of experiences that students bring to class and to illustrate the sensitivity of students to teachers.

Student 3: This session gave us an idea of what to expect in the course... We were shown how sometimes things don't go according to plan. Some people will interpret things differently, as happened today, and this just goes to show how conscious we, as teachers, must be of the instructions that we do or don't give to our students.

This was a powerful experience for [another teacher educator], one that preoccupied her thinking for some time, particularly because she had never thought about her teaching in this way. As I [Berry] write about these experiences, I see how even experienced teachers struggle to recognize the differences between what they intend to teach and their actual teaching behaviors (Berry \& Loughran, 2002, pp. 25-26).

Making the pedagogical reasoning for practice clear, explicit and understandable for student teachers is an important aspect of modeling teaching in teacher education. Talking aloud (Loughran, 
1996) is one way of doing this, but at the heart of this principle is the need for student teachers to see into their teachers' thinking about teaching so that they can access the ideas and feelings associated with taking risks and learning about teaching in meaningful ways.

\section{Binding it all together: views, practices and people}

Recently, the AERA Panel on Research and Teacher Education (Cochran-Smith \& Zeichner, 2005) published the final report on the immense work they carried out in a meta-study, analyzing almost all the North American research on the effectiveness of teacher education. Their final conclusion was somewhat alarming, namely, that there is no clear evidence that certain approaches in teacher education may be more effective than others, and even that it may be questionable whether teacher education can make a difference at all. The results from a study by Brouwer and Korthagen (2005) show that this conclusion may be due to the fact that the approaches were compared on a high level of abstraction, i.e., in terms of general instructional strategies that a program uses. In their study they present empirical evidence that more specific principles guiding the practices within a program may lead to clear and positive outcomes in the graduates of such a program. This suggests an urgent need for identifying such principles, especially principles that support the link between experience and theory in ways that are responsive to the expectations, needs and practices of teacher educators and student teachers. This is what we attempt in this paper.

In almost every teacher education program in the world, one or more of the seven principles can be recognized. We believe, however, that each of the principles is strengthened by the others, and it may thus be too simple to think that adding one principle to a program structure may lead to a significant improvement. There are important interconnections between the principles and, as Fig. 2 shows, they represent three main components of programs or program change, ones that in our view are fundamental to any change in teacher education: (1) the views of knowledge and learning that direct the practices of the teacher educators, (2) program structures and specific practices, and (3) the quality of staff and organization.

Trying to change one principle in any one of the three components without addressing the other components will not, in our view, be very effective. For example, if teacher educators make the important step from building on episteme to developing phronesis, as when they start to see knowledge about teaching as a subject to be created instead of an already created subject (principle 2), this will require helping student teachers to become a strong community of learners in which they work and learn closely together (principle 5). This in turn has consequences for the way teaching practices are organized, which points towards the importance of principle 6 . In other words, we believe it is the coherence across the three components in Fig. 2 that will make a difference.

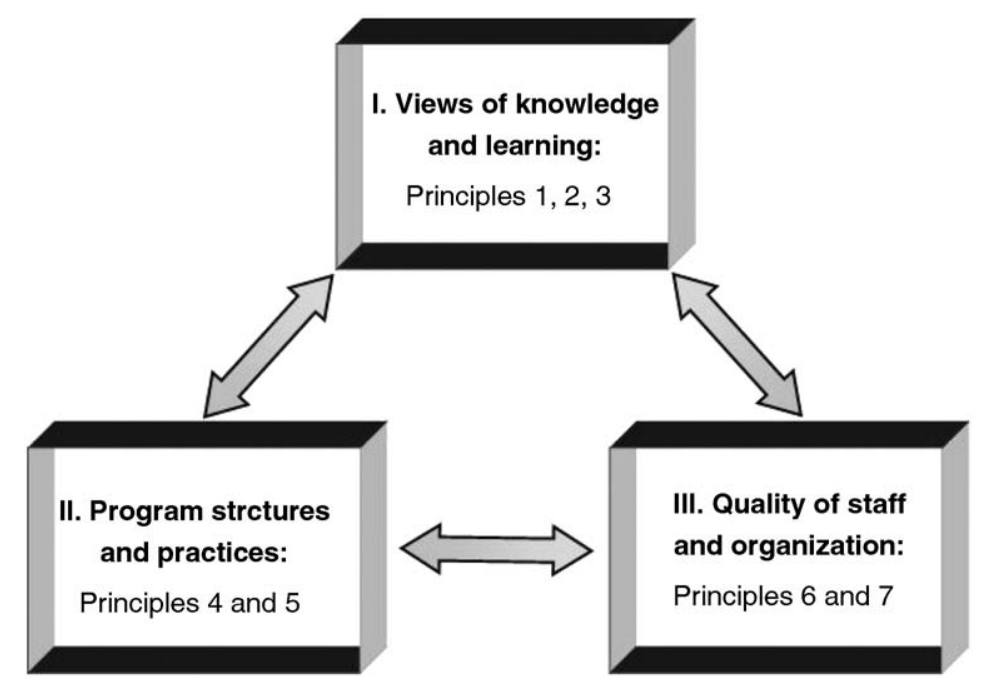

Fig. 2. Clustering of the seven principles into components of programs and program change. 


\section{Program change and development}

We wish to emphasize that this points to a view of program change in teacher education as an in-depth process that may take many years to become effective. As Russell (1999, p. 221) reported: "It is far too easy to propose early changes that fail to give the innovation a clear chance." For example, the Utrecht program, which seems rather successful at bridging the gap between theory and practice (as documented in Korthagen \& Kessels, 1999, and in Brouwer \& Korthagen, 2005), took shape over a period of more than 15 years in which program elements as well as underlying views of learning to teach were constantly discussed, researched and renewed by the teacher educators involved.

The experience of radical program change at Queen's University is also instructive. Although the initial structure for the new program was set in place for 2 years, it might better have been set in place for five years. Within 3 weeks of the completion of the first full year, and with no attempt to collect relevant and systematic data from university or school settings or from those learning to teach, a 1-day faculty retreat resulted in significant changes to that initial structure. Superficially, the changes appeared to respond to the concerns of the most vocal. More deeply, the changes were a major step away from the "learning from experience" premises of the initial structure. The pressure to understand how fundamental premises had been shifted was removed the moment that any change at all was made, for the implicit message was that cries of personal discomfort were sufficient to achieve regression to more comfortable and more traditional structures. That first year did reveal that the Faculty Liaison role was a particularly crucial element in the success of the new structure (Martin, 2001). Those learning to teach knew no other structure, while schools and teachers who received the preservice candidates quite naturally found that the radical changes required significant adjustments, as the new structure intended.

Change in program structures and practices require a corresponding change in thinking about teacher education, with enormous consequences for the daily work of teacher educators. These consequences go well beyond the level of program organization and teaching or supervisory behavior; most of all, an attitudinal shift is involved. Change is a long-term process of staff development (as illustrated in the Utrecht experience in contrast to the Canadian experience) and involves training of faculty, student teachers as well as mentor teachers. Moreover, structures for intercollegially supported learning are crucial if change is to be more than superficial, not least because most teacher educators are appointed to their positions without any specific training for this profession (Korthagen \& Russell, 1995) and often without any support from more experienced colleagues (see Ducharme, 1993).

In many settings, however, component III in Fig. 2 seems to be undervalued: systematic professional development of teacher education faculty is still not a common phenomenon. Experiences in the Netherlands and in other countries where the Utrecht training courses have been offered have shown that a major effect of these courses is that teacher educators come to understand, through personal experience, the significance of learning from one's own concrete work situations. They also come to understand the function as well as the difficulties of reflecting on such situations. This seems to be a prerequisite for real change in teacher education and is one way of addressing the retreat of teacher educators into their individual, isolated teaching spaces and the protective response of private practice that can so dramatically detract from genuine program development inherent in embracing a pedagogy of teacher education.

\section{Conclusion}

There has been a remarkable development of the knowledge base for teaching through extensive educational research over the last four decades. Nevertheless, the theory-practice issue seems intractable: telling new teachers what research shows about good teaching and sending them off to practice has failed to change, in any major way, what happens in our schools and universities. Neither has having teachers write behavioral objectives nor exhorting them to be reflective practitioners produced major leaps forward. At the same time, exploring fundamental assumptions of teacher education associated with its university context has proven difficult to achieve. Despite providing powerful accounts of teacher education's shortcomings, Goodlad's (1990) recommendations appear to have had minimal impact on how new teachers are prepared for their profession.

Here we have attempted to illustrate how the principles we have constructed from our own professional experiences in three teacher education 
programs in very different locations offer ways of developing principles of practice that might more generally shape the nature of teaching and learning about teaching. The articulation of these principles offers one way of building on the need for direct and explicit attention to the place of experience in learning about teaching that is so commonly touted as an important approach for teacher education that makes a difference.

The seven principles presented in this paper illustrate one way of beginning to create a common language for the development of a pedagogy of teacher education. These principles suggest guidelines and possibilities (as opposed to rules and procedures) to those teacher educators willing to accept the challenge of reconstructing teacher education from within. We believe these principles are informative and applicable across contexts and we suggest that they can help to develop new understandings of a pedagogy of teacher education that others might build on and extend in their own programs and practices.

\section{References}

Admiraal, W. F., Lockhorst, D., Wubbels, T., Korthagen, F. A. J., \& Veen, W. (1998). Computer-mediated communication environments in teacher education: Computer conferencing and the supervision of student teachers. Learning Environments Research, 1, 59-74.

Anderson, G. L., Herr, K., \& Nihlen, A. S. (1994). Studying your own school: An educator's guide to qualitative practitioner research. Thousand Oaks, CA: Corwin Press.

Ashton, P. (1996). Improving the preparation of teachers. Educational Researcher, 25(9), 21-22 35.

Baird, J. R., \& Northfield, J. R. (Eds.). (1992). Learning from the PEEL experience. Melbourne, Australia: Monash University.

Barnes, D. A. (1975). From communication to curriculum. Harmondsworth, UK: Penguin.

Barone, T., Berliner, D. C., Blanchard, J., Casanova, U., \& McGowan, T. (1996). A future for teacher education. In J. Sikula, T. Buttery, \& E. Guyton (Eds.), Handbook of research on teacher education (2nd ed., pp. 1108-1149). New York: Macmillan.

Ben-Peretz, M. (1995). Curriculum of teacher education programs. In L. W. Anderson (Ed.), International encyclopedia of teaching and teacher education (pp. 543-547). Oxford: Elsevier Science/Pergamon.

Berry, A. (2004). Self-study in teaching about teaching. In J. J. Loughran, M. L. Hamilton, V. K. LaBoskey, \& T. Russell (Eds.), International handbook of self-study of teaching and teacher education practices (pp. 1295-1332). Dordrecht, The Netherlands: Kluwer.

Berry, A., \& Loughran, J. J. (2002). Developing an understanding of learning to teach in teacher education. In J. Loughran, \& T.
Russell (Eds.), Improving teacher education practices through self-study (pp. 13-29). London: RoutledgeFalmer.

Bode, B. (1940). How we learn. New York: Heath.

Boud, D., Keogh, R., \& Walker, D. (1985). Reflection: Turning experience into learning. London: Kogan Page Ltd.

Brookfield, S. D. (1995). Becoming a critically reflective teacher. San Francisco: Jossey-Bass.

Brouwer, N., \& Korthagen, F. (2005). Can teacher education make a difference? American Educational Research Journal, 42(1), 153-224.

Brown, J. S., Collins, A., \& Duguid, P. (1989). Situated cognition and the culture of learning. Educational Researcher, 18(1), 32-42.

Bullough, R. V., Jr., \& Gitlin, A. (2001). Becoming a student of teaching: Methodologies for exploring self and school context (2nd ed.). London: RoutledgeFalmer.

Bullough, R. V., Jr., \& Kauchak, D. (1997). Partnerships between higher education and secondary schools: Some problems. Journal of Education for Teaching, 23(3), 215-233.

Calderhead, J., \& Gates, P. (Eds.). (1993). Conceptualizing reflection in teacher development. London: Falmer Press.

Carlson, H. L. (1999). From practice to theory: A social constructivist approach to teacher education. Teachers and Teaching: Theory and Practice, 5(2), 203-218.

Clandinin, D. J. (1995). Still learning to teach. In T. Russell, \& F. Korthagen (Eds.), Teachers who teach teachers (pp. 25-31). London: Falmer Press.

Clift, R. T., Houston, R. W., \& Pugach, M. C. (Eds.). (1990). Encouraging reflective practice in teacher education: An analysis of issues and programs. New York: Teachers College Press.

Cobb, P., \& Bowers, J. (1999). Cognitive and situated learning perspectives in theory and practice. Educational Researcher, 28(2), 4-15.

Cochran-Smith, M., \& Lytle, S. L. (1993). Inside/outside: Teacher research and knowledge. New York: Teachers College Press.

Cochran-Smith, M., \& Zeichner, K. M. (Eds.). (2005). Studying teacher education: The report of the AERA panel on research and teacher education. Mahwah, NJ: Lawrence Erlbaum.

Cole, A. L. (1997). Impediments to reflective practice. Teachers and Teaching: Theory and Practice, 3(1), 7-27.

Cole, A. L., \& Knowles, J. G. (1993). Teacher development partnership research: A focus on methods and issues. American Educational Research Journal, 30, 473-495.

Cook-Sather, A. (2002). Authorizing student perspectives: Towards trust, dialogue and change in education. Educational Researcher, 31(4), 3-14.

Damasio, A. R. (1994). Descartes' error: Emotion, reason and the human brain. New York: Grosset Putman.

Darling-Hammond, L. (1994). Professional development schools: Schools for developing a profession. New York: Teachers College Press.

Dewey, J. (1933). How we think. New York: Heath and Co.

Ducharme, E. R. (1993). The lives of teacher educators. New York: Teachers College Press.

Elliot, J. (1991). Action research for educational change. Buckingham: Open University Press.

Feiman-Nemser, S., \& Floden, R. (1986). The cultures of teaching. In M. Wittrock (Ed.), Handbook of research on teaching (3rd ed., pp. 505-526). New York: Macmillan.

Fenstermacher, G. D. (1997). Foreword. In J. Loughran, \& T. Russell (Eds.), Teaching about teaching: Purpose, passion and 
pedagogy in teacher education (pp. viii-xiii). London: Falmer Press.

Fosnot, C. T. (1996). Constructivism: Theory, perspectives, and practice. New York: Teachers College Press.

Freudenthal, H. (1978). Weeding and sowing: Preface to a science of mathematical education. Dordrecht, The Netherlands: Reidel.

Galesloot, L. J., Koetsier, C. P., \& Wubbels, Th. (1997). Handelingsaspecten bij wederzijds leren van ervaren docenten [Aspects of acting in reciprocal learning of experienced teachers]. Pedagogische Studiën, 74, 249-260.

Goodlad, J. I. (1990). Teachers for our nation's schools. San Francisco: Jossey-Bass.

Grimmett, P. P., \& Erickson, G. L. (Eds.). (1988). Reflection in teacher education. New York: Teachers College Press.

Hamilton, M. L. (Ed.). (1998). Reconceptualising teaching practice: Self-study in teacher education. London: Falmer Press.

Hermans, J. J., Créton, H. A., \& Korthagen, F. A. J. (1993). Reducing the gap between theory and practice in teacher education. In J. T. Voorbach (Ed.), Teacher education 9, research and developments on teacher education in the Netherlands (pp. 111-120). De Lier: Academisch Boeken Centrum.

Kessels, J. P. A. M., \& Korthagen, F. A. (1996). The relationship between theory and practice: Back to the classics. Educational Researcher, 25(3), 17-22.

Koetsier, C. P., \& Wubbels, T. (1995). Bridging the gap between teacher training and teacher induction. Journal of Education for Teaching, 21(3), 333-345.

Koetsier, C. P., Wubbels, T., \& Korthagen, F. A. J. (1997). Learning from practice: The case of a Dutch post-graduate teacher education programme. In M. I. Fuller, \& A. J. Rosie (Eds.), Teacher education and school partnerships (pp. 113-132). New York: Edwin Mellen Press.

Korthagen, F. A. J. (1985). Reflective teaching and preservice teacher education in the Netherlands. Journal of Teacher Education, 36(5), 11-15.

Korthagen, F. A. J., \& Kessels, J. P. A. M. (1999). Linking theory and practice: Changing the pedagogy of teacher education. Educational Researcher, 28(4), 4-17.

Korthagen, F., \& Russell, T. (1995). Teachers who teach teachers: Some final considerations. In T. Russell, \& F. Korthagen (Eds.), Teachers who teach teachers: Reflections on teacher education (pp. 187-192). London: Falmer Press.

Korthagen, F. A. J., Kessels, J., Koster, B., Lagerwerf, B., \& Wubbels, T. (2001). Linking practice and theory: The pedagogy of realistic teacher education. Mahwah, NJ: Lawrence Erlbaum Associates.

LaBoskey, V. K. (1994). Development of reflective practice. New York: Teachers College Press.

LaBoskey, V. K. (2004). The methodology of self-study and its theoretical underpinnings. In J. J. Loughran, M. L. Hamilton, V. K. LaBoskey, \& T. Russell (Eds.), International handbook of self-study of teaching and teacher education practices (pp. 817-869). Dordrecht, The Netherlands: Kluwer.

Lanier, J., \& Little, J. W. (1986). Research in teacher education. In M. C. Wittrock (Ed.), Handbook of research on teaching (3rd ed., pp. 527-560). New York: MacMillan.

Lather, P. (1991). Getting smart: Feminist research and pedagogy within the postmodern. New York: Routledge.

Lortie, D. (1975). Schoolteacher. Chicago: University of Chicago Press.
Loughran, J. (1996). Developing reflective practice: Learning about teaching and learning through modelling. London: Falmer Press.

Loughran, J. (1997). Teaching about teaching: Principles and practice. In J. Loughran, \& T. Russell (Eds.), Teaching about teaching: Purpose, passion and pedagogy in teacher education (pp. 57-69). London: Falmer Press.

Loughran, J. (2002). Effective reflective practice: In search of meaning in learning about teaching. Journal of Teacher Education, 53, 33-43.

Loughran, J. (2006). Developing a pedagogy of teacher education: Understanding teaching and learning about teaching. London: Routledge.

Loughran, J., \& Russell, T. (Eds.). (1997). Purpose, passion and pedagogy in teacher education. London: Falmer Press.

Martin, A.K. (2001, May). Twin peaks: Perspectives on practice and collaboration. Paper presented at the meeting of the Canadian Society for the Study of Education, Québec City, Québec.

McIntyre, D., \& Hagger, H. (1992). Professional development through the Oxford Internship Model. British Journal of Educational Studies, 40(3), 264-283.

Merriam, S. B. (1998). Qualitative research and case learning applications in education. San Francisco: Jossey-Bass.

Müller-Fohrbrodt, G., Cloetta, B., \& Dann, H. D. (1978). Der Praxisschock bei jungen Lehrern [The transition shock in beginning teachers]. Stuttgart, Germany: Klett.

Myers, C. B. (2002). Can self-study challenge the belief that telling, showing, and guided practice constitute adequate teacher education? In J. Loughran, \& T. Russell (Eds.), Improving teacher education practices through self-study (pp. 130-142). London: RoutledgeFalmer.

Northfield, J. R., \& Gunstone, R. F. (1983). Research on alternative frameworks: Implications for science teacher education. Research in Science Education, 13, 185-192.

Northfield, J. R., \& Gunstone, R. F. (1997). Teacher education as a process of developing teacher knowledge. In J. Loughran, \& T. Russell (Eds.), Teaching about teaching: Purpose, passion and pedagogy in teacher education (pp. 48-56). London: Falmer Press.

Osterman, K. F., \& Kottkamp, R. B. (1993). Reflective practice for educators: Improving schooling through professional development. Thousand Oaks, CA: Corwin Press.

Putnam, R. T., \& Borko, H. (1997). Teacher learning: Implications of new views of cognition. In B. J. Biddle, T. L. Good, \& I. F. Goodson (Eds.), International handbook of teachers and teaching, vol. II (pp. 1223-1296). Dordrecht/Boston/London: Kluwer Academic Publishers.

Richardson, V. (Ed.). (1997). Constructivist teacher education: Building new understandings. London: Falmer Press.

Russell, T. (1995). Returning to the physics classroom to re-think how one learns to teach physics. In T. Russell, \& F. Korthagen (Eds.), Teachers who teach teachers (pp. 95-109). London: Falmer Press.

Russell, T. (1999). The challenge of change in teaching and teacher education. In J. R. Baird (Ed.), Reflecting, teaching, learning: Perspectives on educational improvement (pp. 219-238). Cheltenham, Victoria, Australia: Hawker Brownlow Education.

Russell, T. (2002). Guiding new teachers' learning from classroom to experience: Self-study of the faculty liaison role. In 
J. Loughran, \& T. Russell (Eds.), Improving teacher education practices through self-study (pp. 73-87). London: RoutledgeFalmer.

Sandlin, R. A., Young, B. L., \& Karge, B. D. (1992). Regularly and alternatively credentialed beginning teachers: Comparison and contrast of their development. Action in Teacher Education, 14(4), 16-23.

Schön, D. A. (1983). The reflective practitioner: How professionals think in action. New York: Basic Books.

Schön, D. A. (1987). Educating the reflective practitioner. San Francisco: Jossey-Bass.

Segall, A. (2002). Disturbing practice: Reading teacher education as text. New York: Peter Lang.

Sigel, I., \& Cocking, R. (1977). Cognitive development from birth to adolescence: A constructivist perspective. New York: Holt, Rinehart \& Winston.

Stake, R. E., \& Trumbull, D. (1982). Naturalistic generalisations. Review Journal of Philosophy and Social Science, 7(1 and 2), $1-12$.

Stevenson, R. (1996). What counts as "good" action research? Paper presented at the Ethnography in Educational Research Forum, Philadelphia.

Stofflett, R. T., \& Stoddart, T. (1994). The ability to understand and use conceptual change pedagogy as a function of prior content learning experience. Journal of Research in Science Teaching, 31, 31-51.

Tigchelaar, A., \& Melief, K. (2000). Peer supported learning for students on paid practice: Student teachers learn to supervise one another. In G. M. Willems, J. H. J. Stakenborg, \& W. Veugelers (Eds.), Trends in Dutch teacher education (pp. 185-195). Apeldoorn, The Netherlands/Leuven, Belgium: Garant/VELON.
Tom, A. (1997). Redesigning teacher education. Albany: State University of New York Press.

Upitis, R. (Ed.). (2000). Who will teach? A case study of teacher education reform. San Francisco: Caddo Gap Press.

Van Manen, M. (1999). The language of pedagogy and primacy of student experience. In J. Loughran (Ed.), Researching teaching: Methodologies and practice for understanding pedagogy (pp. 13-27). London: Falmer Press.

Vedder, J. (1984). Oriëntatie op het beroep van leraar [Orientation towards the teaching profession]. Lisse: Swets \& Zeitlinger.

Vedder, J., \& Bannink, P. (1987). The development of practical skills and reflection at the beginning of teacher training. Paper presented at the meeting of the Association of Teacher Education in Europe, Berlin.

Veenman, S. (1984). Perceived problems of beginning teachers. Review of Educational Research, 54, 143-178.

Wideen, M., Mayer-Smith, J., \& Moon, B. (1998). A critical analysis of the research on learning to teach: Making the case for an ecological perspective on inquiry. Review of Educational Research, 68, 130-178.

Zeichner, K., \& Gore, J. (1995). Using action research as a vehicle for student teacher reflection: A social reconstructionist approach. In S. E. Noffke, \& R. Stevenson (Eds.), Educational action research: Becoming practically critical (pp. 13-130). New York: Teachers College Press.

Zeichner, K. M., \& Noffke, S. E. (2001). Practitioner research. In V. Richardson (Ed.), Handbook of research on teaching (4th ed., pp. 298-330). Washington, DC: American Educational Research Association.

Zeichner, K., \& Tabachnick, B. R. (1981). Are the effects of university teacher education washed out by school experiences? Journal of Teacher Education, 32, 7-11. 